\title{
SHORE ECOLOGY IN THE SUB-ANTARCTIC
}

\author{
by Rod Simpson
}

(with two tables)

\begin{abstract}
Simpson, R.D. 2007 (23:xi): Shore ecology in the sub-Antarctic. Papers and Proceedings of the Royal Society of Tasmania 141(1): 95-98. https://doi.org/10.26749/rstpp.141.1.95 ISSN 0080-4703. University of New England, National Marine Science Centre, PO Box J321, Coffs Harbour, NSW 2450, Australia.

Research on the shores in the sub-Antarctic region is discussed with respect to how lines of investigation developed, current status, and what areas of research should attract priority in relation to both outstanding questions and concerns for the ecological well-being of the region. The remoteness of the sub-Antarctic requires coordination of effort and resources and it is suggested that greater advances could be made if there is international coordination in a more prescribed way.
\end{abstract}

Key Words: sub-Antarctic, shore ecology.

\section{INTRODUCTION}

The following is not intended as an exhaustive review of the works that have been conducted on thebiotaand ecology of the seashores of the sub-Antarctic region; rather, it concentrates on the type of work that has been done and what directions might be the more gainfil for future research, taking into account the status of the research so far, the features of the region and current global concerns.

Shore ecology is used here to refer to the marine benthic biota of the littoral and sublittoral areas. The seashores support other animals. Penguins and seals use the seashore for segments of their life-cycles, particularly breeding, but the ecology of these animals is treated by researchers of these groups in other parts of these proceedings.

\section{THE REGION AND THE ISLANDS}

The nature of the region and the location and sizes of the islands within the region are identified by Selkirk (2007) and Quilty (2007). Seashore ecology is influenced by a number of factors. The islands are scattered across a virtually unimpeded oceanic region with a "west wind drift" as a dominating nearsurface influence. The positions of the Antarctic Convergence and the sub-Antarctic Polar Frontal Zone have a strong influence. The harsh yet seasonally equable weather in many regions, the difficulty of access for study, and the influence of the current global increases in sea water temperature are all important factors.

\section{CURRENT STATUS OF RESEARCH}

In 1988, I reviewed studies of sub-Antarctic shores, with particular reference to Macquarie Island (Simpson 1988). That publication outlines the beginnings of research in the region, leading to a statement on the status of research at that time. The present status of research shows advances in some areas. In summary, the first research involved collections during early expeditions and the first years of occupancy of sub-Antarctic bases. Taxonomic studies allowed the first evaluations of the biogeographical affinities across the islands, to temperate regions to the north, and to the Antarctic in the south. Descriptive ecology followed, centred on the distributions of biota in the littoral and sublittoral and how those distributions related to the contemporary concepts of zonation (see Simpson 1988). More specific ecological studies examined causes influencing the distribution of biota, such as physiological tolerances, predation and competition, including comparisons with work in temperate regions where similarities and differences were drawn. A further area of research that has received considerable attention is the reproduction of marine invertebrates. The harsh climatic conditions and the geographic isolation of scattered sub-Antarctic islands provides a fertile ground for linking reproductive modes with ecological and distributional extremes (see Simpson 1988).

What has happened since 1988? Research into previously studied areas has continued and some new ones opened up. Tables 1 and 2 are compiled from a survey of 65 publications up to 2006 that deal with shore biota and ecology across the more studied locations from the sub-Antarctic region. Table 1 shows the research topics undertaken at these locations and table 2 ranks the frequency with which these topics are covered within the publications surveyed. In some cases, more than one topic or location are entered from the one publication. Further subdivision into more topics would be possible (e.g., algae, echinoderms). More exhaustive searching may alter the middle rankings slightly but the two tables give a good indication of the research attention to shore biota and ecology in the sub-Antarctic. There is little doubt that taxonomy would remain first in frequency of publication output as the survey did not include all the initial taxonomic papers that examined specimens collected during the early expeditions. It is not the intention here to provide a list of references behind these tables or to provide commentary on the merits of the works across such a wide spectrum. Researchers would need to conduct their own searches in specific areas of interest.

\section{CURRENT AND FUTURE PRIORITIES IN RESEARCH}

What should be the priorities for future research work in the sub-Antarctic? These must be weighed against the difficulties and constraints in logistics, financial support and time, in getting to this remote region of the world.

Taxonomic work should continue wherever and whenever those with the expertise can provide time to work on material from the sub-Antarctic. By providing more definitive 
TABLE 1

Topics of investigation across the sub-Antarctic

\begin{tabular}{|c|c|c|c|c|c|c|c|c|}
\hline & Macquarie & Kerguelens & Sth Georgia & $\begin{array}{c}\text { Marion and } \\
\text { Prince Edward }\end{array}$ & Heard & Crozets & $\begin{array}{l}\text { South America to } \\
\text { Antarctic Peninsula }\end{array}$ & $\begin{array}{l}\text { Circum sub- } \\
\text { Antarctic }\end{array}$ \\
\hline Taxonomy & $\mathrm{x}$ & $\mathrm{x}$ & $\mathrm{x}$ & $\mathrm{x}$ & $\mathrm{x}$ & $\mathrm{x}$ & $\mathrm{x}$ & $\mathrm{x}$ \\
\hline $\begin{array}{l}\text { Biogeography and } \\
\text { distribution }\end{array}$ & $\mathrm{x}$ & $\mathrm{x}$ & $x$ & $\mathrm{x}$ & & & $\mathrm{x}$ & $\mathrm{x}$ \\
\hline Littoral algae & $x$ & & $\mathrm{x}$ & $\mathrm{x}$ & $\mathrm{x}$ & & $\mathrm{x}$ & \\
\hline Littoral fauna and ecology & $\mathrm{x}$ & $\mathrm{x}$ & $x$ & $\mathrm{x}$ & $\mathrm{x}$ & & $\mathrm{x}$ & \\
\hline Molluscan ecology & $\mathrm{x}$ & $\mathrm{x}$ & $\mathrm{x}$ & $\mathrm{x}$ & & & $\mathrm{x}$ & \\
\hline Reproduction & $\mathrm{x}$ & $\mathrm{x}$ & & & & & $\mathrm{x}$ & \\
\hline Beach fauna & & & $\mathrm{x}$ & & & & & \\
\hline Physiological & $\mathrm{x}$ & $\mathrm{x}$ & $x$ & & & & $\mathrm{x}$ & \\
\hline Biochemistry & & $\mathrm{x}$ & & & & & & \\
\hline Community Structure & $\mathrm{x}$ & & & & & & $\mathrm{x}$ & \\
\hline Pollution & $\mathrm{x}$ & & & & & & $\mathrm{x}$ & \\
\hline Sublittoral & $\mathrm{x}$ & & $\mathrm{x}$ & & & & $\mathrm{x}$ & \\
\hline $\begin{array}{l}\text { Monitoring for species } \\
\text { introductions }\end{array}$ & $\mathrm{x}$ & & & & & & $x$ & \\
\hline
\end{tabular}

TABLE 2

Ranking of frequency of topics investigated

\begin{tabular}{lll}
\hline Rank & $\begin{array}{c}\text { Frequency } \\
\text { (from 65 publications) }\end{array}$ & \multicolumn{1}{c}{ Topic } \\
\hline 1 & 25 & Taxonomy, including biogeographical inferences \\
2 & 16 & Littoral ecology (flora and fauna) \\
3 & 12 & Reproductive ecology \\
4 & 11 & Molluscan ecology \\
5 & 6 & Community structure, population dynamics \\
5 & 6 & Physiology and biochemistry \\
7 & 5 & Pollution ecology \\
8 & 4 & Sublittoral ecology \\
8 & 4 & Mechanisms of distribution \\
10 & 2 & Monitoring for introduction of species \\
11 & 1 & Beaches \\
\hline
\end{tabular}

phylogenetic relationships for the biota of the region, distributional pathways of the past and of the future can be better understood. The project on the Census of Marine Life is a significant step towards this goal. However, as O'Hara (1998a) pointed out in examining the echinoderms of Macquarie Island, the nature of the Southern Ocean and the breakup of Gondwana are likely to have promoted polymorphism in isolated species complexes. This presents problems not only for taxonomy but also for attempts to trace origins and past and present distributional pathways.

Molecular taxonomic methods will be useful in consolidating the strength or otherwise of relationships among sub-Antarctic biota. This should be a priority research area because understanding the geographic origins of the biota, coupled with knowledge of distributional and recruitment pathways, will assist in determining measures (where possible and/or deemed necessary) to meet changes induced by human activities, either those that have a direct impact or those that have an indirect effect such as that from global climate changes.

A dramatic event occurred when the supply ship M.V. Nella Dan ran aground at Macquarie Island in December 1987, spilling marine diesel onto the shoreline. This unfortunate event provided a springboard for pollution studies on sub-Antarctic shores, not only for the immediate effects but also for understanding the degree of persistence of pollution in these waters (Pople et al. 1990, Simpson et al. 1995, Smith \& Simpson 1995, Smith \& Simpson 1998). With more frequent human visitation and use in these areas, a means of monitoring any disturbance against knowledge of a previous background is required. The shoreline is an area that can provide a laboratory of organisms that signal change in marine conditions. Smith \& Simpson (1995) showed that the fauna of holdfasts of the giant kelp Durvillaea antarctica (Chamisso) show considerable promise in this regard. These holdfasts support a high diversity of 
fauna at the interface of the shore and the sea, provide a natural and discrete sampling unit, represent a habitat across the entire region, and the faunal community within the holdfasts reflects both natural gradients and disturbance from pollution (such as oiling).

Concomitant with concerns about pollution disturbance is the possible introduction of alien species, particularly via shipping and human visitation. Species extensions through their own distributional capabilities in response to climate change will be such large and widespread events that little can be done, except to remedy the root cause itself, such as global warming. The laissez faire approach would be to say that, in the case of global warming for instance, it is insignificant in comparison to the long-term natural cycles of the planet. There is even a more controversial view, that the more direct influence of humans is a "new evolution" for the planet, so live with it. I don't think we can or should take such chances. Thus, monitoring for species introductions should also be a priority research area.

Understanding recruitment and reproductive interchange within and across invertebrate populations in the subAntarctic is a foremost step for evaluating the causes and possible remedies for adverse disturbances, whatever the sources. Research into these questions forms another priority.

One area that requires confirmation is the long-held view that kelp-rafting by fauna is a vector for dispersal of marine invertebrates across the Southern Ocean. If this is so, it could provide a mechanism for dispersal of exotic species. Smith (2002) revealed the potential for such a dispersal mechanism in calculations from a shipboard observation program that indicated 70 million rafts of Durvillaea antarctica afloat at any one time between the latitudes of $46-53^{\circ} \mathrm{S}$. Further, 20 million of these could have a holdfast attached, and this holdfast provides an extra haven for a diversity of fauna. Survival of invertebrates would need to be verified. Helmuth et al. (1994) showed that the brooding bivalve, Gaimardia trapesina (Lamarck, 1819), was capable of longterm survival on kelp rafts as shown from collections of kelp rafts approaching the shores of South Georgia. O'Hara (1998b) cautioned that dispersal by the West Wind Drift could be overstated and that both separation processes and shelf/slope migrations along submarine ridges and plateaux have played a significant role in determining the faunal composition and distributions across the Southern Ocean. Again, molecular techniques to define the ancient and recent affinities among populations would greatly assist in providing answers to these questions.

\section{COORDINATION OF RESEARCH}

The above priorities need not be the only research undertaken. All areas of research must allow for the topics of discovery that add to knowledge with as yet unforeseen outcomes. The extra logistic requirements and difficulties for work in the sub-Antarctic region prompt a coordinated effort to ensure the best uses of available funds and support structures. Ideally, an international approach would greatly assist in that a central body could call for research proposals with indications of favoured themes. Allowing this body to control the funding from different countries would be difficult to implement but the sub-Antarctic, an international area, almost demands such an approach. Whatever the decision process and whoever the decision makers, attention to selection of supported research will become more critical with threats of change with uncertain consequences.

The questions are obvious and have been addressed in the programs of some countries across all fields of study, such as: how to best coordinate the logistical and funding support; the balance between contracted versus discovery research; is research into disturbance and management the top priority?; offshore vs. onshore; and what are the organisms and/or populations to study?

The need and the opportunity are both there to give greater attention to these questions, hopefully at the level of international coordination.

\section{REFERENCES}

Helmuth, B., Veit, R.R. \& Holberton, R. 1994: Long-distance dispersal of a subantarctic brooding bivalve (Gaimardia trapesind) by kelp-rafting. Marine Biology 120: 421426.

O'Hara, T. D. 1998a: Systematics and biology of Macquarie Island echinoderms. Memoirs of Museum Victoria 57(2): $167-223$.

O'Hara, T.D. 1998b: Origin of Macquarie island echinoderms. Polar Biology 20: 143-151.

Pople, A., Simpson, R.D. \& Cairns, S.C. 1990: An incident of Southern Ocean oil pollution: effects of a spillage of diesel fuel on the rocky shore of Macquarie Island (subAntarctic). Australian Journal of Marine and Freshwater Research 41: 603-620.

Quilty, P.G. 2007: Geophysics and geological history of the sub Antarctic islands. Papers and Proceedings of the Royal Society of Tasmania 141(1): 35-58.

Selkirk, P.M. 2007: The nature and importance of the subAntarctic, Papers and Proceedings of the Royal Society of Tasmania 141(1): 1-6.

Simpson, R.D. 1988: Developments in the studies of subantarctic shores, with particular reference to Macquarie Island. Papers and Proceedings of the Royal Society of Tasmania 122(1): $211-217$.

Simpson, R.D., Smith, S.D.A. \& Pople, A.R. 1995: The effects of a spillage of diesel fuel on a rocky shore in the SubAntarctic region (Macquarie Island). Marine Pollution Bulletin 31(4-12): 367-371.

Smith, S.D.A. 2002: Kelp rafts in the Southern Ocean. Global Ecology and Biogeography 11(1): 67-69.

Smith, S.D.A. \& Simpson, R.D. 1995: Effects of the "Nella Dan" oil spill on the fauna of Durvillaea antarctica holdfasts. Marine Ecology Progress Series 121: 73-89.

Smith, S.D.A. \& Simpson, R.D. 1998: Recovery of benthic communities at Macquarie Island (subantarctic) following a small oil spill. Marine Biology 131: 567-581.

(accepted 24 September 2007) 